\title{
Application of Moringa oleifera for Development of Sustainable and Biosecure Aquaculture
}

\author{
${ }^{1 \mathrm{a}}$ Manoj T. Kamble *, ${ }^{2}$ Balu R. Chavan, ${ }^{l a}$ Ataguba Gabriel, ${ }^{3}$ Txomin Azpeitia ${ }^{1 \mathrm{~b}}$ Seema V. \\ Medhe, ${ }^{1 \mathrm{~b}}$ Surangna Jain, and ${ }^{1 \mathrm{~b}}$ Rakesh R. Jadhav \\ ${ }^{1 a}$ Aquaculture and Aquatic Resource Management, \\ ${ }^{1 b}$ Food Engineering and Bioprocess technology, \\ School of Environment Resources and Development, \\ Asian Institute of Technology, P.O. Box 4, Klong Luang, Pathumthani 12120, Thailand \\ ${ }^{2}$ Marine Biological Research Station (Dr.B.S.K.K.V. Dapoli), Ratnagiri 415612, Maharashtra, India \\ ${ }^{3}$ Aquaculture Projects Consultant, Huay Kwang, Bangkok 10310, Thailand \\ Correspondence to: maav.manya@gmail.com
}

\begin{abstract}
Manoj T. Kamble, Balu R. Chavan, Ataguba Gabriel, Txomin Azpeitia, Seema V. Medhe, Surangna Jain, and Rakesh R. Jadhav. 2014. Application of Moringa oleifera for Development of Sustainable and Biosecure Aquaculture. Aquacultura Indonesiana, 15 (2) : 64-73. As the global scenario is now changing towards the development of sustainable and bio-secured aquaculture by using of safe and ecofriendly products. This paper reviews the properties and applications of Moringa plant in aquaculture. The Moringa products have been shown to possess many properties that can apply in aquaculture. These properties include antimicrobial activity, larvicidal activity, piscicide, and, antifertility properties. The plant can also be used as a food supplement and as seafood preservative. The use of Moringa seed coat and pod husks as antimicrobial substances or as a medicinal plant have reported in shrimp where Penaeus indicus were found to protect from pathogenic Vibrio harveyi. There was also an evidence for cyanobactericidal activity of filtrate from crushed Moringa seeds that a protease inhibitor isolated. In conclusion, this review suggests that Moringa oleifera is a valuable plant that could be used for development of sustainable aquaculture
\end{abstract}

Keywords: Activity; Antimicrobial; Aquaculture; Moringa; Sustainable

\section{Introduction}

Sustainable aquaculture developments focus on increasing aquaculture production and productivity to alleviate poverty and hunger without compromising the environment. Aquaculture is the fastest-growing food production sector in the world and now supplies almost half of the global fish consumption. Trends in many of the drivers of demand indicate that aquaculture continue to expand. In particular, Asian and African aquaculture must grow significantly to meet domestic and regional demand for fish by increasing production by using underutilized water resources.

In the aquaculture, fish farmers always encounter predatory problem during the stocking of new fish species, and most often, they tend to use synthetic chemicals, which are nonbiodegradable, as an effective solution. The biosafety of products from aquaculture is paramount to consumers of aquatic foods from the aquaculture source. M. oleifera is biodegradable, environmentally friendly and cost-effective, and could use as supplemental protein source for fishmeal, and as aquaculture pond management tool to wipe predators in the fish pond prior to stocking with new fish species (Adesina and Omitoyin, 2011). Focus on plant research has increased all over the world and a large amount of data has collected which shows enormous potential of medicinal plants used in various traditional systems. Many herbs have developed into herbal supplements which are claimed to assist in healthy lifestyle (Sirimongkolvorakul et al., 2011).

M. oleifera (Lam) belongs to the family Moringaceae and is commonly called drumstick tree, horseradish West India Bern tree or "Miracle tree". The Moringa plant has been the object of much research due to its multiple uses and well-known bactericidal activity. It is rich in nutrients and, apart from a range of industrial and medicinal applications, is used to purify water for human consumption (Vieira et al., 2010). As the global scenario is now changing towards the use of safe and eco-friendly products, development of modern drugs from traditional medicinal plants should be emphasized for the control of various human and animal diseases. M. oleifera is one such plant which has been reported to possess many medicinal properties (Dewangan et al., 2010). M. oleifera is a natural nutrition plant in tropic countries. The leaves, fruits, flowers and immature pods used as a highly nutritive 
vegetable. This plant contains a profile of essential minerals, good source of protein, vitamins, amino acids, $\beta$-carotene and various phenolics. In addition, all parts of the tree are considered to possess medicinal properties, such as cardiac and circulatory stimulant, possess antitumor, antipyretic, anti-inflammatory, antiulcer, antispasmodic, antihypertensive, cholesterol lowering, antioxidant, antidiabetic, hepatoprotective, antibacterial and antifungal activities (Anwar et al., 2007).

High nutrient of the $M$. oleifera leaves is promoted as "Trees for life", by an NGO based in the United States. Gram for gram fresh leaves of $M$. oleifera have 4 times the vitamin A of carrots, 7 times the vitamin $\mathrm{C}$ of oranges, 4 times the calcium of milk, 3 times the potassium of bananas, $3 / 4$ the iron of spinach and 2 times the protein of yogurt (Lotaka and Piyatiratitivorakul, 2012). Antimicrobial resistance has become a global public health problem impacted both by human and non-human microbial usage (WHO, 2001 and 2003 and Henning, 2006). There is an increasing demand for medicinal plants and plant products as alternative to orthodox medicines, especially in developing countries. Synthetic chemicals and alum has for years been used, as fish disinfectant, and therapeutant. However recently, attention has been shifted to plant based chemical, for water treatments and possibly as therapeutic. Recently, M. oleifera seed powder has been tested and proved to have better performance in purifying turbid water, but little work has done on the toxicity of $M$. oleifera seed powder to some important cultivable fish species. Moringa plants are widely available in the tropic. Their leaves, fruits, bark and roots have economic importance for industrial and medicinal uses (Ayotunde et al., 2011 ${ }^{\mathrm{a}}$ ). In this paper, published data on Moringa plant extract and any of its use in aquaculture were extensively reviewed and analyzed.

\section{Properties and Applications of Moringa Plant in Aquaculture}

\section{Antimicrobial Activity}

Medicinal herbs are moving from the fringe to mainstream use with a greater number of people seeking for remedies and health approaches from side effects caused by synthetic chemicals. It has aggravated the search for antimicrobials from plant sources. Rajamanickam and Sudha, (2013) conducted a study to obtain the preliminary information on the phytonutrient profile, toxicity, and antimicrobial property of
Allamanda cathartica and $M$. oleifera against clinical pathogens. The effects of antibiotic sensitivity test showed that petroleum ether extract of $A$. cathartica and ethanolic extract of $M$. oleifera showed better antimicrobial property against many pathogens including Staphylococcus aureus, Escherichia coli, Bacillus sp., Pseudomonas aeruginosa, Cornebacterium sp., Klebsiella pneumonia, and Acinetobacter sp. than other extracts. However, methanol extracts of $M$. oleifera inhibit bacteria better than ethanol extracts (Oluduro 2012), but Pal et al. (1995) reported the effectiveness of ethanolic extracts of M. oleifera against both gram positive and negative bacteria. Bichi et al. (2012) on the other hand, reported that a combination of hexane oil extraction and aqueous extraction followed by freeze drying produced an extract with greater antimicrobial activity compared to standard aqueous extraction, salt extraction and a combination of hexane extraction and these methods. In general, natural drugs have much less side effects when compared to that of synthetic and other chemical drugs (Table 2). Efficacy of some extracts is better than others primarily due to the method of extraction. Methanol extracted products present better results for antimicrobial activity than other methods.

Onsare et al. (2013) reported the use of aqueous extracts of $M$. oleifera samples from different areas of India against two yeast strains, three Gram positive and seven Gram negative bacteria by agar well diffusion assay. In that report, the extracts from seed coat, stem bark and pod husks were found to be organism specific with minimal inhibition concentration (MIC) ranged from $0.5-1.25 \mathrm{mg} / \mathrm{mL}, 3.0-4.2 \mathrm{mg} / \mathrm{mL}$ and 4.0 - $5.6 \mathrm{mg} / \mathrm{mL}$, respectively (Table $1^{\mathrm{A}}$ ). Both seed's coat and pod's husks extracts exhibited microbicidal properties which were totally inhibited at 10 and 12 hours respectively. The seed coat extract was the most effective against $E$. coli at zero hours, while some pathogens, treated with stem bark extract, exhibited regrowth again after 24 hours apparently. Antimicrobial activity of the seed coat and pod husks reported for the first time. The active constituents may be considered potential candidates for the development of broad spectrum antimicrobial drugs. It also is in agreement with Oluduro (2012) who found that aqueous and methanolic extracts of $M$. oleifera showed visible inhibitory effects against bacteria but was not effective against Aspergillus flavus whereas ethanolic extract was effective against 
many fungi. Pal et al. (1995), used ethanolic extracts from the leaves of $M$. oleifera and found that efficacy also was specific and decreased in the order: E. coli >Bacillus subtilis $>$ Mycobacterium phlei >Bacillus cereus $>$ Micrococcus luteus $>S$. aureus. This point to the fact that leaves, seed coat and pod husk of M. oleifera possess antimicrobial constituents that can be extracted using either methanol, ethanol, or a combination of hexane and aqueous extraction which showed high potency against bacteria as demonstrated by Bichi et al. (2012).

Onyuka et al. (2013) reported the effectiveness of the $M$. oleifera plant extracts against bacteria in fish samples, which was never described before (Table 2). It means that $M$. oleifera plants that easily grow in most arid and sandy conditions, as found near the Lake Victoria basin in Kenya, can be exploited to provide extracts for preserving fish for long term storage and safety for human populations. Ekanem et al. (2011) evaluated the antibacterial effectiveness of seven plant extracts against Aeromonas and Pseudomonas bacteria of farmed catfish (Heterobranchus longifilis). The results from this study have demonstrated that preparations from medicinal plants have potentials for the control of A. hydrophila and $P$. fluorescens in cultured catfish. M. oleifera showed antibacterial activities against $A$. hydrophila and $P$. fluorescens of $H$. longifilis with MIC of $50 \mathrm{mg} / \mathrm{mL}$ (Table 2). The high host tolerance to the plant extracts is also an indication that a reliable therapeutic regime could develop from herbal products for the treatment of aquaculture diseases. This discovery from various plants involved the use of leaf and bulb or fruit extracts using ethanol as solvent. Although efficacy was recorded, for some plants, others were not as effective. It is quite clear that parts of the plant used for extraction of the antimicrobial agent affects its effectiveness. Allium cepa bulb extract did not inhibit A. hydrophila and P. fluorescens of $H$. longifilis (Ekanem et al., 2011) but Muniruzzaman and Chowdhury (2004) reported the effectiveness of ethanol extracted A. cepa leaf extract against $A$. hydrophila, $P$. fluorescens and Edwardsiella tarda. The difference in part of the plant used is responsible for the disparity of results coupled with the fact that Ekanem et al. (2011) used other solvents apart from ethanol that was, however, the significant solvent (70\%).

Table $1^{\mathrm{A}}$ : Efficacy of Moringa with aqueous extracts in controlling/reducing the population of pathogenic bacteria

\begin{tabular}{|c|c|c|c|c|}
\hline Parts used & Target species & Activity/Effect & Concentration/ Biological Activity & Reference \\
\hline Seed & Anopheles gambiae & Larvicidal & $\begin{array}{l}72 \text { hour- LC50 and LC } 90 \text { of } 1885.4 \\
\mu \mathrm{g} / \mathrm{mL}, 3902.4 \mu \mathrm{g} / \mathrm{mL} \text { respectively, } \\
(P<0.05) \text {, causing } 99.33 \pm 1.15 \% \\
\text { mortality at } 8700 \mu \mathrm{g} / \mathrm{mL} .\end{array}$ & $\begin{array}{l}\text { Ohia et al., } \\
2013\end{array}$ \\
\hline Seed & Poecilia reticulata & Toxicity & $\begin{array}{l}\text { Toxic reactions (erratic movements, air } \\
\text { gulping with prolonged exposure resulted } \\
\text { in dullness and discoloration in higher } \\
\text { concentrations) }\end{array}$ & $\begin{array}{l}\text { Ohia et al., } \\
2013\end{array}$ \\
\hline Seed & $\begin{array}{l}\text { Staphylococcus aureus, } \\
\text { Vibrio cholerae } \\
\text { Escherichia coli }\end{array}$ & Antibacterial & $\begin{array}{l}1: 5 \text { and } 1: 10 \text { in volumes } 50,100,150 \text { and } \\
200 \mu \mathrm{L} \text { were efficiently inhibited (halo }> \\
13 \mathrm{~mm} \text { ) the growth of bacteria isolated } \\
\text { from shrimp samples, especially at } 150 \\
\text { and } 200 \mu \mathrm{L} / \text { dish. }\end{array}$ & $\begin{array}{l}\text { VIEIRA et } \\
\text { al., } 2010\end{array}$ \\
\hline $\begin{array}{l}\text { Seeds coat, } \\
\text { bark, } \\
\text { pods husks }\end{array}$ & $\begin{array}{l}\text { Staphylococcus aureus, } \\
\text { Staphylococcus } \\
\text { epidermidis, Shigella } \\
\text { flexneri,Salmonella } \\
\text { typhimurium, Escherichia } \\
\text { coli,Klebsiella pneumonia, } \\
\text { Pseudomonas aeruginosa, } \\
\text { Salmonella typhimurium, } \\
\text { Candida albicans }\end{array}$ & Antimicrobial & $\begin{array}{l}\text { totally inhibited at } 10 \text { and } 12 \mathrm{~h} \\
\text { respectively }\end{array}$ & $\begin{array}{l}\text { Onsare } \text { et } \\
\text { al., } 2013\end{array}$ \\
\hline Seed Coat & Escherichia coli & Antimicrobial & $\begin{array}{l}\text { Seeds' coat extract was the most effective } \\
\text { against E. coli at } 0 \text { hours }\end{array}$ & $\begin{array}{l}\text { Onsare } \text { et } \\
\text { al., } 2013\end{array}$ \\
\hline
\end{tabular}


Vieira et al. (2010) found antibacterial activity (inhibition halo $>13 \mathrm{~mm}$ ) against S. Aureus (Gram positive), Vibrio cholerae and E. coli (Gram negative) isolated from the whiteleg shrimp (Litopenaeus vannamei) using aqueous and ethanolic seed extracts of Moringa. While E. coli isolated from tilapia, Oreochromis niloticus, was sensitive to the ethanolic extract of Moringa. However, LC50 of $242 \mathrm{mg} / \mathrm{L}$ of seed extract has been reported by Ayotunde et al. $\left(2011^{\mathrm{a}}\right)$. While histological changes such as gill degeneration, gill arch hypertrophy, as well as liver and kidney hyperplasia, necrosis, and vacuolation have seen with severity increasing with concentration of seed extracts (Ayotunde $e t$ al., 2011 ${ }^{\mathrm{b}}$ ). Dewangan et al. (2010) conducted an experiment to determine the antibacterial activity of different extracts of $M$. oleifera root bark against $S$. aureus, E. coli, Salmonella gallinarum and $P$. aeruginosa in vitro (Table 2 ). Both the gram-positive and gram-negative organisms showed variable sensitivity to different extracts of $M$. oleifera root bark in organic solvents as methanol, acetone, ethyl acetate and chloroform and in the inorganic solvent, water. In general, ethyl acetate and acetone extracts showed maximum antibacterial activity. The aqueous extract had minimum antibacterial activity against the test organisms.

\section{Larvicidal Activity}

Plant-based insecticides have been long proposed as alternatives to synthetic chemical insecticides for vector and pest control because they pose little threat to human and environmental health (Choochote et al., 1999 and Murray, 2006). Several plants around the world have identified with insecticidal (larvicidal, pupicidal and adulticidal) properties against mosquitoes either in the seeds, fruits, barks, roots or their root exude. The diversity of plant species is huge and phytochemicals obtained from them are important sources of safe and biodegradable chemicals which can screen for mosquito and insecticidal activities and test for safety in mammals (Mittal and Subbarao, 2003).

Ohia et al. (2013) evaluated the aqueous extract of the Moringa oleifera seed as a control agent against third instar larvae of Anopheles gambiae in the laboratory. It showed that it was larvicidal to the mosquito species and with very minimal toxic effects seen in the non-target animal, Poecilia reticulate (Table $1^{\mathrm{A}}$ ). These results suggest that $M$. oleifera may be a potentially valuable source of insecticide and may well play a more prominent role in mosquito control programs in the future. Similarly, Njom et al. (2011) assessed the toxicity and growth regulatory effects of $M$. oleifera seed extracts on third larval instars of Anopheles gambiae, under laboratory conditions. At highest and lowest concentrations of $5 \% \mathrm{w} / \mathrm{v}$ and $1 \% \mathrm{w} / \mathrm{v}$, larval mortality in a day was $80 \%$ and $10 \%$, respectively. No adult emerged in higher concentrations though the few adults that emerged in lower concentrations were too weak to fly. This study clearly showed that $M$. oleifera seed extract has larvicidal and growth inhibitory effects on larvae of Anopheles gambiae.

Prabhu et al. (2011) conducted a study on larvicidal and repellent potential of $M$. oleifera against malarial vector, Anopheles stephensi Liston (Insecta: Diptera: Culicidae). This study indicates that the phytochemicals derived from $M$. oleifera seeds extracts are effective anti-mosquito agents and the plant extracts may use for further integrated pest management programs. Low toxicity of $M$. oleifera has reported in mice and daphnia (Ferreira et al., 2009) but $100 \%$ mortality of simulium larvae has reported with the use of petroleum extract of M. oleifera (Etusim et al., 2013). The use of oil extracted from M. oleifera as a method of controlling the armyworm (Spodoptera frugiperda) was demonstrated by Kamel (2010). It indicates that the extract from M. oleifera is also effective against other insect larvae. The effectiveness of the extract against both human disease vectors and plant pests shows its versatility and importance in ensuring food security and social wellbeing.

\section{Piscicide}

Elimination of unwanted fish is a common practice among fish farmers prior to stocking with desirable fish fingerlings. However, the synthetic piscicides used to eliminate unwanted fish are persistent and could get into the food chain. Thus, the use of environmentally safe organic piscicides as an alternative is being embraced in aquaculture because they are biodegradable over short periods, and there is a possibility that the fish killed by them are edible with no health hazards (Chiayvareesajja et al., 1997; Agbon et al., 2004; Akinbulumo et al., 2004; Akinwande et al., 2007). M. oleifera is suggested as an alternative to synthetic piscicides because it is commonly 
available, is less expensive for fish farmers and has a lower toxicity against non-target species. Adesina and Omitoyin (2011) conducted a study on the potential of $M$. oleifera fresh root-bark extract as an organic piscicide in aquaculture pond management. The results of the study revealed that the fish exposed to fresh root-bark extract of $M$. oleifera at different concentrations exhibited toxic responses which eventually lead to death. This extract could use as an organic piscicide in aquaculture pond management, and baseline information on its toxicity to fish could serve as a fisheries management tool to wipe out predatory fishes in ponds prior to stocking.

Adesina et al. (2013) reported that biosafety of food products from aquaculture is now considered as a public health concern in Nigeria. It is due to the nature and component of materials used as rearing facilities on the fish farm. Elimination of unwanted fishes and other predators is a common practice among fish farmers in Nigeria prior to stocking of desirable fish fingerlings (Table $1^{\mathrm{B}}$ ). The use of synthetic pesticides to eliminate unwanted fishes and other predators in the pond is persistent and could get into the food chain. Thus, the use of environmentally safe, natural pesticides as an alternative is being embraced in aquaculture because they have a short period of toxicity disappearance and biodegradable. It enhances the principles of sustainable aquaculture production and its management in Nigeria.

\section{Anti-cyanobacterial Activity}

Climate change is expected to aggravate hazardous blooms of Cyanobacteria (Paerl and Huisman, 2008) while safe and aesthetically acceptable water is a growing need in a modern society (Steffensen, 2008). Hence, water resource management is challenged worldwide to reduce the vulnerability to the threats of harmful cyanobacterial blooms. Particularly in developing countries where the high costs of chemicals for water and wastewater treatment might limit their application, the development of cost-effective and environmentally acceptable mitigating measures is beneficial. In that context, water clarification and disinfection with natural products, such as the seeds of the pan-tropical tree, $M$. oleifera, is of particular interest. Lurling and Beekman, (2010) stated that presumably, in the higher doses of 20- to 160-mg crushed seeds per liter, the cyanobacteria would die. At the highest dosage of $160 \mathrm{mg} / \mathrm{L}$, the efficiency of photosystem II (ФPSII) dropped to zero rapidly and remained nil during the experiment that lasted 14 days $\left(\right.$ Table $1^{\mathrm{B}}$ ). Hence, under laboratory conditions, a complete wipeout of the bloom could be achieved. It is the first study that yielded evidence for cyanobactericidal activity of filtrate from crushed Moringa seeds, suggesting that Moringa seed extracts might have a potential as an effect-oriented measure lessening cyanobacterial nuisance.

Table $1^{\mathrm{B}}$ : Efficacy of Moringa with aqueous extracts in controlling/reducing the population of pathogenic bacteria.

\begin{tabular}{|c|c|c|c|c|}
\hline $\begin{array}{l}\text { Parts } \\
\text { used }\end{array}$ & $\begin{array}{l}\text { Target } \\
\text { species }\end{array}$ & Activity/E & Concentration/ Biological Activity & Reference \\
\hline Seeds & $\begin{array}{l}\text { Microcystis } \\
\text { aeruginosa }\end{array}$ & $\begin{array}{l}\text { Anti- } \\
\text { Cynobacterial }\end{array}$ & $\begin{array}{l}\text { Good growth in controls and treatments with } 4-\text { and } 8-\mathrm{mg} \\
\text { crushed Moringa seeds per liter, having similar growth rates of } \\
0.50( \pm 0.01) \text { per day. In exposures of } 20 \text { - to } 160-\mathrm{mg} \text { crushed } \\
\text { Moringa seeds L- } 1 \text {, growth rates were negative and on average } \\
-0.23( \pm 0.05) \text {.day }-1 \text {. }\end{array}$ & $\begin{array}{l}\text { Lurling and } \\
\text { Beekman, } \\
2010\end{array}$ \\
\hline Seeds & Nile tilapia & Toxicity & $\begin{array}{l}\text { 24-h, 48-h, 72-h and 96-h LC50 of M includes erratic } \\
\text { movement, air gulping, loss of reflex, discoloration, molting, } \\
\text { loss of scale, and hemorrhage. }\end{array}$ & $\begin{array}{l}\text { Ayotunde et } \\
\text { al., } 2004\end{array}$ \\
\hline $\begin{array}{l}\text { Root } \\
\text { Bark }\end{array}$ & Nile tilapia & $\begin{array}{l}\text { organic } \\
\text { piscicide }\end{array}$ & $\begin{array}{l}\text { Acute-lethal toxicity (LC) of Moringa oleifera extract for } 96-\mathrm{h} \\
\text { exposure for Tilapia fingerlings was determined at } 26.45 \mathrm{mg} \mathrm{l-1}\end{array}$ & $\begin{array}{l}\text { Adesina and } \\
\text { Omitoyin } \\
2011\end{array}$ \\
\hline seed & Nile tilapia & Toxicity & $\begin{array}{l}\text { The pack cell volume increased from } 17.5 \pm 0.7 \text { in the control to } \\
23.0 \pm 4.2 \text { in concentration of } 17.5 \pm 0.7 \text { in the control to } 23.0 \pm 4.2 \\
\text { in concentration of } 250 \mathrm{mg} / \mathrm{L} \text { Moringa/ liter of water. }\end{array}$ & $\begin{array}{l}\text { Ayotunde et } \\
\text { al., } 2011\end{array}$ \\
\hline seed & Nile tilapia & $\begin{array}{l}\text { Histological } \\
\text { Changes }\end{array}$ & $\begin{array}{l}\text { Pathologic lesions observed: } \\
\text { levels of cells degeneration in the gill, lamellar hyperemia; } \\
\text { hypertrophy of gill arch occurred, while hyperplasia, } \\
\text { disarrangement of hepatic cell, necrosis, } \\
\text { vacuolation occurred in fish liver and kidney }\end{array}$ & $\begin{array}{l}\text { Ayotunde } e t \\
\text { al., } 2011\end{array}$ \\
\hline
\end{tabular}




\section{Antifertility Effect}

Ampofo-Yeboah et al. (2013) conducted a study on the effect of Moringa seed powder on the gonadal integrity of Mozambique Tilapia, Oreochromis mossambicus. The result of the study indicated that including Moringa seed powder at $5.0 \mathrm{~g} / \mathrm{kg}$ basal diet and higher inclusion levels have an antifertility effect, significantly affecting gonad integrity and sperm production in sexually mature $O$. mossambicus males.

\section{Food Supplement}

Kumalaningsih et al. (2011) conducted a study on encapsulation of Lactobacillus sp. with M. oleifera leaves extract for food supplement. He concluded that the addition of Moringa leaf extract increased the growth of lactic acid bacteria. The use of $8 \% \mathrm{M}$. oleifera leaves extract is the best treatment for making encapsulated food supplement. The feeding trial showed that the food supplement increased the weight of rats approximate by $30 \%$. Rayes (2013) investigated the effect of dietary $M$. oleifera leaf for the first time in aquaculture as a medicinal plant for protection of $P$. indicus from pathogenic $V$. harveyi. The study found that survival of shrimp juvenile in $M$. oleifera leaves was $86.4 \%$. The study also indicated that $M$. oleifera leaves contained appreciable amounts of carbohydrate, protein and minerals, which are the nutritional requirements of all livestock animal. Possibly, the leaves from this plant could be useful as feed supplement and as a medicine in poultry to improve health and increase performance. Lotaka and Piyatiratitivorakul (2012) concluded that the supplementation of $M$. oleifera leaf powder in the diet after 63 days had no adverse effect on the shrimp survival. The results also indicated that M. oleifera leaves could be an alternative herb for improvement of marine shrimp culture by conducting an experiment on effects of supplemented diets on growth, survival and immune response of pacific white shrimp (Litopenaeus vannamei).

\section{Seafood Preservative}

Bijina et al. (2011) conducted a study on protease inhibitor from $M$. oleifera with potential for use as therapeutic drug and as seafood preservative. Among the different parts of $M$. oleifera tested, the crude extract isolated from the mature leaves and seeds showed the highest level of inhibition against trypsin. Among the various extraction media evaluated, the crude extract prepared in phosphate buffer showed maximum recovery of the protease inhibitor. The protease inhibitor recorded high inhibitory activity toward the serine proteases thrombin, elastase, chymotrypsin and the cysteine proteases cathepsin B and papain which have more importance in the pharmaceutical industry. The protease inhibitor also showed complete inhibition of the activities of the commercially available proteases of Bacillus licheniformis and Aspergillus oryzae. However, inhibitory activities toward subtilisin, esperase, pronase $\mathrm{E}$ and proteinase $\mathrm{K}$ were negligible. Further, it was found that the protease inhibitor could prevent proteolysis in a commercially valuable shrimp Penaeus monodon during storage indicating the scope for its application as a seafood preservative. It is the first report on the isolation of a protease inhibitor from $M$. oleifera. Onyuka et al. (2013) conducted a study on the comparison of the antimicrobial activities of brine salting, chlorinated solution and M. oleifera plant extracts in fish from the Lake Victoria basin of Kenya. The results of this study show that for the two fish species Raillardella argentea and O. niloticus, $12 \%$ sodium chloride solution was the most effective in reducing bacterial load, compared to chlorinated solution even at the highest concentration of $200 \mathrm{mg} / \mathrm{L}$ (Table 2). 
Table 2: Efficacy of Moringa with different solvent extracts in controlling/reducing the population of pathogenic bacteria

\begin{tabular}{|c|c|c|c|c|c|}
\hline $\begin{array}{l}\text { Solvent } \\
\text { Extract }\end{array}$ & parts used & Target species & Activity/Effect & Concentration/ Biological Activity & Reference \\
\hline \multirow[t]{4}{*}{ Ethanol } & dry seed & $\begin{array}{l}\text { Enteric bacteria in } \\
\text { Rastrineobola } \\
\text { argentea } \\
\text { Oreochromis } \\
\text { niloticus }\end{array}$ & Antimicrobial & $\begin{array}{l}\text { At } 8 \text { hours, microbial load was } 536.6 \\
\text { MPN/g at control } 0 \mu \mathrm{g} \text { and this } \\
\text { decreased to } 144.3 \mathrm{MPN} / \mathrm{g} \text { at } \mathrm{M} \text {. } \\
\text { oleifera ethanol extract concentration } \\
\text { at } 80 \mu \mathrm{g} / \mathrm{mL} \text { at } 8 \text { hours, } \mathrm{P}=0.00001 \text {. }\end{array}$ & $\begin{array}{l}\text { Onyuka et } \\
\text { al., } 2013\end{array}$ \\
\hline & Leaf & $\begin{array}{l}\text { Aeromonas } \\
\text { Pseudomonas } \\
\text { bacteria }\end{array}$ & Antibacterial & $\begin{array}{l}\text { less sensitive to } A \text {. hydrophila and } \\
\text { effective against } P \text {. flourescens }\end{array}$ & $\begin{array}{l}\text { Ekanem et } \\
\text { al., } 2011\end{array}$ \\
\hline & leaf & $\begin{array}{l}\text { S. aureus, E. coli, } \\
\text { Bacillus sp., } P . \\
\text { aeruginosa, } \\
\text { Cornebacterium } \\
\text { s, Klebsiella } \\
\text { pneumonia, } \\
\text { Acinetobacter sp. }\end{array}$ & Antimicrobial & $\begin{array}{l}\text { Significant inhibition (S. aureus }(20 \\
\mathrm{mm}), \text { E. coli }(20 \mathrm{~mm}), \text { Bacillus } \mathrm{sp} . \\
(18 \mathrm{~mm}), \text { P. aeruginosa }(14 \mathrm{~mm}) \text {, } \\
\text { Cornebacterium sp. }(12 \mathrm{~mm}), \\
\text { Klebsiella pneumonia }(12 \mathrm{~mm}), \\
\text { Acinetobacter } \mathrm{sp} .(14 \mathrm{~mm})) .\end{array}$ & $\begin{array}{l}\text { Rajamanic } \\
\text { kam and } \\
\text { Sudha, } \\
2013\end{array}$ \\
\hline & leaf & $\begin{array}{l}\text { red-tail tinfoil } \\
\text { barb }\end{array}$ & Lead Toxicity & $\begin{array}{l}24 \text { hours LC50 lead exposure, } \\
\text { hepatocytes were showed } \\
\text { cytoplasmatic vacuolation with } \\
\text { hypertrophy and pycnotic nuclei. }\end{array}$ & $\begin{array}{l}\text { Sirimongk } \\
\text { olvorakul } \\
\text { et al., } 2011\end{array}$ \\
\hline $\begin{array}{l}\text { Methanol, } \\
\text { acetone, } \\
\text { ethyl } \\
\text { acetate, } \\
\text { chloroform }\end{array}$ & Root bark & $\begin{array}{l}\text { Staphylococcus } \\
\text { aureus, } \\
\text { Escherichia coli, } \\
\text { Salmonella } \\
\text { gallinarum } \\
\text { Pseudomonas } \\
\text { aeruginosa }\end{array}$ & Antibacterial & $\begin{array}{l}\text { variable sensitivity to different } \\
\text { extracts }\end{array}$ & $\begin{array}{l}\text { Dewangan } \\
\text { et al., } 2010\end{array}$ \\
\hline n-hexane & Seed & $\begin{array}{l}\text { Enteric bacteria in } \\
\text { Rastrineobola } \\
\text { argentea } \\
\text { Oreochromis } \\
\text { niloticus }\end{array}$ & Antimicrobial & $\begin{array}{l}\text { At } 8 \mathrm{~h} \text { the control tilapia }(0 \mu \mathrm{g} / \mathrm{mL}) \\
\text { had a microbial load of } 326.2 \mathrm{MPN} / \mathrm{g} \\
\text { and at } 80 \mu \mathrm{g} / \mathrm{mL} \text { it decreased to } 87 \\
\text { MPN/g, P=0.00001 }\end{array}$ & $\begin{array}{l}\text { Onyuka et } \\
\text { al., } 2013\end{array}$ \\
\hline
\end{tabular}

\section{Toxicity Effect}

Despite widespread use of Moringa, its toxicity and effectiveness to aquatic organisms, particularly fishes, have not been examined. Acute and chronic toxicity test was conducted using aqueous extract of $M$. oleifera seeds on the most widely cultivated African freshwater fishes. Sirimongkolvorakul et al. (2011) presented a study on the influence of $M$. oleifera on histopathological changes due to lead toxicity in red-tail tinfoil barb, Puntius altus. The present study revealed that the crude leaves powder of $M$. oleifera has a potential to reduce lead toxicity. The greater potency of $M$. oleifera leaves against lead could be due to the antioxidant property or chelating properties. Thus, they recommend that a suitable selection and manipulation of their diet might be useful for a significant extent in reducing toxicity risk in populations exposed to lead. Ayotunde et al. (2004) conducted acute and chronic toxicity tests using aqueous extracts of $M$. oleifera seeds on $O$. niloticus fingerlings and adults in order to provide baseline information and establish a limit of using aqueous extracts of $M$. oleifera seeds in freshwater fish ponds. Hematological examination of the fingerlings showed (Table $1^{\mathrm{B}}$ ) an increase in red blood cell (RBC), white blood cell (WBC), packed cell volume (PCV), hemoglobin $(\mathrm{Hb})$, mean corpuscular hemoglobin (MCH) and mean corpuscular hemoglobin concentration (MCHC) values. While there was a decrease in the erythrocyte sedimentation rate (ESR), $\mathrm{MCH}$, and mean corpuscular volume (MCV) values. Whereas in the adults, the RBC, PCV, $\mathrm{Hb}$ and $\mathrm{MCH}$ values increased and there was a decrease in the ESR, WBC and MCV, while there was no 
change $(P>0.05)$ in $\mathrm{MCHC}$ values. Mortality increased with increase in concentration of $M$. oleifera and time of exposure in both $O$. niloticus fingerlings and adults.

Ayotunde et al. $\left(2011^{\mathrm{a}}\right)$ determined the toxicity of $M$. oleifera seed powder to the most cultivable fish species in Africa, tilapia, Oreochromis niloticus, fingerlings (Table $\left.1^{\mathrm{B}}\right) . M$. oleifera seed powder is a good water purifier; it contains polyelectrolytes, which constitute active ingredients in water treatment. The histological changes in the gill, skin, liver and kidney include different level of degeneration of cells, lamellar hyperemia; hypertrophy of gill arch, shrinkage and dermal erosion and necrosis of the skin. While hyperplasia, disarrangement of hepatic cell, necrosis, and vacuolation occurred in liver and kidney of tilapia fingerling. The damages became severe with increasing concentration of M. oleifera to fish and time of exposure. There was no significant difference in water quality in the test, the result obtained before the test, during the test and after the test. It found close to the water quality parameters of the control. The results of the test provided baseline information and established safe limit of using an aqueous extract of M. oleifera seed powder in fresh water pond. It ascertained that aqueous extract of $M$. oleifera seed powder did not have adverse effects on water quality. Ayotunde et al. $\left(2011^{\mathrm{b}}\right)$ defined the pathological effects of $M$. oleifera seed powder, natural alternative to alum, used as a water purifier in a fish culture enclosure in Nigeria $\left(\right.$ Table $1^{\mathrm{B}}$ ). The histological changes in gill, liver, skin and kidney of fingerling and adult of Nile tilapia exposed to aqueous extract of $M$. oleifera seed at different sub-lethal concentration under static bioassay procedure described. There were pathologic lesions observed, which included different levels of cell degeneration in the gill, lamellar hyperemia; hypertrophy of gill arch occurred while hyperplasia, disarrangement of hepatic cell, necrosis, and vacuolation occurred in fish liver and kidney. Damages of different organs became severe with increasing concentration of aqueous extract of $M$. oleifera seeds and time of exposure.

\section{Conclusion}

After analysis of available information on Moringa plant regarding its potentials to contribute multipurpose use in sustainable aquaculture found that Moringa exhibited multipurpose activities. These activities include antimicrobial activity, larvicidal activity, organic piscicide, anti-cyanobacterial activity, antifertility effect, food supplement and seafood preservative. Reliable therapeutic regime could develop from Moringa products for the treatment of aquaculture diseases. These results suggest that $M$. oleifera may be a potentially valuable novel plant for sustainable aquaculture in the future.

\section{References}

Adesina, B.T., O.A. Oguntuga, K.A.A. Raimi, and J.B. Ogunremi. 2013. Guide to Large Scale Production of Moringa oleifera (Lam.) for Sustainable Aquaculture Development in Nigeria: Prospects and Challenges. Agrosearch, 3 (13): 186 - 194.

Adesina, B.T. and B.O. Omitoyin. 2011. Potential of Moringa Oleifera (Lam.) Fresh Root-Bark Extract as an Organic Piscicide in Aquaculture Pond Management. Egyptian Journal of Biology, 1 (13): 8-13.

Agbon, A., C. Ofojekwe, and I. Ezenwaka. 2004. Acute toxicity of water extract of Tephrosia vogelii Hook to species relevant in aquaculture ponds: rotifers, Cyclops, mosquito larvae and fish. Journal of Applied Ichthyology, 20: 521-525.

Akinbulumo, M.O., O.A. Fagbenro, and E.A. Fasakin. 2004. Acute toxicity of ethanolic extract of Derris elliptica root to Oreochromis niloticus fingerlings. In: Proceedings of an International Symposium on Tilapia aquaculture, Manilla, Philippines, 12-16 September. Accessed on line http://ag.arizona.edu/azaque/ista/istab/istabw eb/ web/health.httm on 10/24/2006: 223.

Akinwande, A.A.A., A.O. Sogbesan, F.O. Moody, and A.A.A. Ugwumba. 2007. Piscicidal potential of mesocarp of neem plant (Azadirachta indica A.Juss.) fruit on hybrid, "Heteroclarias". Journal of Environmental Biology, 28 (3): 533-6.

Anwar, F., S. Latif, M. Ashraf, and A.H. Gilani. 2007. Phytother Res., 21:17-25.

Ayotunde, E.O., O.A. Fagbenro, O.T. Adebayo, And A.I. Amoo. 2004. Toxicity of Aqueous Extracts of Drumstick, Moringa Oleifera, Seeds to Nile Tilapia, Oreochromis Niloticus, Fingerlings and Adults. International Research Journal of Agricultural Science and Soil Science, 1 (4) : 142-150.

Ayotunde, E.O., O.A. Fagbenro, and O.T. Adebayo. 2011 a . Histological Changes in Oreochromis niloticus (Linnaeus I779) Exposed to Aqueous Extract of Moringa oleifera Seeds Powder. Turkish Journal of Fisheries and Aquatic Sciences, 11: 37-43. 
Ayotunde, E.O., O.A. Fagbenro, and O.T Adebayo. $2011^{\mathrm{b}}$. Toxicity of aqueous extract of Moringa oleifera seed powder to Nile tilapia Oreochromis niloticus. International Research Journal of Agricultural Science and Soil Science, 1 (4) : 142-150.

Ampofo-Yeboah, A., D. Brink, and H. Lambrechts. 2013. The Effect of Moringa Seed Powder Moringa Oleifera on Gonadal Integrity of Mozambique Tilapia Oreochromis mossambicus. World Aquaculture Society: Aquaculture.

Bichi, M.H, J.C. Agunwamba, S.A. Muyibi, and M.I. Abdulkarim. 2012. Effect of Extraction Method on the Antimicrobial Activity of Moringa oleifera Seeds Extract. Journal of American Science, 8 (9) : 450 - 458

Bijina, B., S. Chellappan, J.G. Krishna, S.M. Basheer, K.K. Elyas, A.H. Bahkali, and M. Chandrasekaran. 2011. Protease Inhibitor from Moringa Oleifera with Potential for use as Therapeutic Drug and as Seafood Preservative. Saudi Journal of Biological Sciences, 18: 273-281.

Chiyvareesajja, S., N. Rittibhonbhun, M. Hongpranyart, and $P$. Wiriyacchitra. 1997. Toxicity of the Thai piscicidal plant Maesa ramentacea to freshwater fish in ponds. Aquaculture, 158 (3/4): 229-34.

Choochote, W., D.A. Kanjanapothi, T. Taesotikul, A. Jitpakdi, U. Chaithong, and B Pitasawat. 1999. Larvicidal adulticidal and repellent effects of Kaempferia galanga. Southeast Asian Journal of Tropical Medicine and Public Health, 30:470-476.

Dewangan, G., K.M. Koley, V.P. Vadlamudi, A. Mishra, A. Poddar, and S.D. Hirpurkar. 2010. Antibacterial activity of Moringa Oleifera (drumstick) root bark. J. Chem. Pharm. Res., 2 (6):424-428.

Ekanem, A.P., A.P. Inyang-Etoh, and P.C. InyangEtoh. 2011. Evaluation of the antibacterial efficacy of seven plant extracts against Aeromonas and Pseudomonas bacteria of farmed catfish (Heterobranchus longifilis). Veterinary Science Development, 1:47-51.

Etusim, P.E, K.U. Uwom, P.E. Melariri, O.O. Ibeh, and C.I. Ogbonnaya. 2013. A study on the toxicity of the ethanol extract of Moringa oleifera seed oil on Simulium larvae. Journal of Biologic al Sciences and Bioconservation, 5 (1): 86 - 91.

Ferreira, P.M.P., A.F.U. Carvalho, D.F. Farias, N.G. Cariolano, V.M.M. Melo, M.G.R. Queiroz, A.M.C. Martins, and J.G. Machado-Neto. 2009. Larvicidal activity of the water extract of Moringa oleifera seeds against Aedes aegypti and its toxicity upon laboratory animals. Anais da Academia Brasileira de Ciências, 81(2): 207 - 216.
Henning, S. 2006. Antimicrobial drug resistance in fish pathogens. In: FM Aarestrup (ed.) Antimicrobial Resistance in Bacteria of Animal origin, ASM Press, Washington, DC, USA: 213-38.

Kamel, A.M. 2010. Can we use the Moringa oil as botanical insecticide against Spodoptera frugiperda? Academic Journal of Entomology, 3 (2): 59 - 64.

Kumalaningsih, S., M. Padaga, Suprayogi, and R.P. Vitta. 2011. Encapsulation of Lactobacillus sp. with Moringa oleifera leaves extract for food supplement. International Research Journal of Agricultural Science and Soil Science (ISSN: 2251-0044), 1(7) : 273-277

Lotaka, R. and S. Piyatiratitivorakul. 2012. Effects of Diets Supplemented with Drumstick Moringa Oleifera Leaf on Growth, Survival and Immune Response of Pacific White Shrimp LitopenaeusVannamei. (C) $38^{\text {th }}$ Congress on Science and Technology of Thailand.

Lurling, M. and W. Beekman. 2010. AntiCyanobacterial Activity of Moringa Oleifera seeds. J. Appl. Phycol., 22:503-510.

Mittal, P.K. and S.K. Subbarao. 2003. Prospects of using herbal products in mosquito control. ICMR Bulletin, 33 (1):1-10.

Muniruzzaman, M. and M.B.R. Chowdhury. 2004. Sensitivity of fish pathogenic bacteria to various medicinal herbs. Bangladesh Journal of Veterinary Medicine, 2:75 - 82.

Murray, B.I. 2006. Botanical Insecticides, Deterrents and Repellents in modern and an increasingly regulated world. Annual review of entomology, 51:45-66.

Njom, V. Stephen, Eze, and C. Simon. 2011. Toxicity and Life Expectancy Effects of Moringa Oleifera Seed Extracts on the Larvae of Anopheles Gambiae. Animal Research International, 8 (2): 1388 - 1391

Ohia, C.M.D., G.R.E.E. Ana, and O.M. Bolaji. 2013. Larvicidal Activity of Aqeous Extract of Moringa oleifera Seeds on Anopheles gambiae and its Effects on Poecilia reticulata. Agrosearch, 13 (3): 176 - 185.

Oluduro, A.O. 2012. Evaluation of Antimicrobial properties and nutritional potentials of Moringa oleifera Lam.leaf in South Western Nigeria. Malaysian Journal of Microbiology, 8 (2): $59-67$.

Onsare, J.G., H. Kaur, and D.S. Arora. 2013. Antimicrobial activity of Moringa oleifera from different locations against some human pathogens. Academia Journal of Medicinal Plants, 1(5): 080-091.

Onyuka, J.H.O., R. Kakai, P.F. Arama, and J. Onyuka. 2013. Comparison Of Antimicrobial Activities of Brine Salting, 
Chlorinated Solution and Moringa Oleifera Plant Extracts in Fish From Lake Victoria Basin of Kenya. African Journal of Food, Agriculture Nutrition and Development, 3(13):7772-7788.

Pal, S.K, P.K Mukherjee, K. Saha, M. Pal, and B.P. Saha. 1995. Antimicrobial action of the leaf extracts of Moringa oleifera Lam. Ancient Science of Life, XIV (3):197-199.

Paerl, H.W. and J. Huisman. 2008. Blooms like it hot. Science, 320 : 57-58.

Prabhu, K., K. Murugan, A. Nareshkumar, N. Ramasubramanian, and S. Bragadeeswaran. 2011. Larvicidaland Repellent Potential of Moringa Oleifera against Malarial Vector, Anopheles Stephensi Liston (Insecta: Diptera: Culicidae). Asian Pacific Journal of Tropical Biomedicine, 124-129.

Rajamanickam, K. And S.S. Sudha. 2013. In-Vitro Antimicrobial Activity And In-Vivo Toxicity of Moringa Oleifera and Allamanda cathartica against Multiple Drug Resistant Clinical Pathogens. International Journal of Pharma Bio Sciences, 4 (1):768 - 775.

Rayes, A.A.H. 2013. Study on the effect of dietary probiotic bacteria Arthrobacter species, $\beta-1,3$ glucan and Moringa oleifera leaf on protection of Penaeus indicus Juveniles from pathogenic Vibrio harveyi. Researcher, 5 (1) : 24-31.

Sirimongkolvorakul, S., W. Jiraungkoorsku, T. Tansatit, N. Preyavichyapugdee, P. Kosai, and K. Uakulwarawat. 2011. Influence of Moringa oleifera on histopathological changes due to lead toxicity in red-tail tinfoil barb, Puntius altus. Proceedings of the $3^{\text {rd }}$ International CEMEPE and SECOTOX Conference Skiathos, 9-14.

Steffensen, D.A. 2008. Chapter 37: economic cost of cyanobacterial blooms. In: Hudnell KE (ed) Cyanobacterial harmful algal blooms: state of the science and research needs. Adv. Exp. Med. Biol., (619):855-865.

Vieira, G.H.F., J.A. Mourao, A.M. Ângelo, A.R. Costa, and R.H.S.F. Vieira. 2010. Antibacterial Effect (In Vitro) of Moringa Oleifera and Annona muricata against Gram Positive and Gram Negative Bacteria. Rev. Inst. Med. Trop. Sao Paulo, 52 (3) :129-132.

WHO. 2001. Monitoring of antimicrobial usage in food animals for the protection of human health. Report of a WHO consultation, Oslo, Norway. Available from: http://www.who.int/emc/ diseases/zoo/antimicrobial.html

World Organisation for Animal Heath, WHO, FAO. 2003. Joint FAO/OIE/WHO 1st Expert workshop on non-human antimicrobial usage and antimicrobial resistance: scientific assessment. Geneva, Switzerland, 1http://www.who.int/foodsafety/ publications/micro/en/report.pdf. 